\title{
ANALISIS BIAYA PERSEDIAAN BAHAN BAKU IKAN DAN PERHITUNGAN ECONOMIC ORDER QUANTITY (EOQ) PADA RUMAH MAKAN IKAN BAKAR KINAMANG
}

\author{
Melinda Miranda Wijaya ${ }^{1}$, David P. E. Saerang ${ }^{2}$, Meily Y. B. Kalalo ${ }^{3}$ \\ ${ }^{1,2,3}$ Fakultas Ekonomi dan Bisnis, Jurusan Akuntansi, Universitas Sam Ratulangi, Jl. Kampus Bahu, Manado, \\ 95115, Indonesia \\ E-mail : melindawijaya88@gmail.com
}

\begin{abstract}
The cost of raw material inventory is a sacrifice of economic resources, measured in units of money, which have occurred or are likely to occur for raw material inventory, consisting of purchase costs, storage costs, and inventory shortage. This study aims to determine (1) Total Inventory Cost (TIC) based on RM policy. Kinamang Fuel Fish and Economic Order Quantity (EOQ) method during 2017 (2) Frequency of ordering of efficient fish raw material during 2017 (3) Quantity of safety stock and when to reorder point of raw materials fish in RM. Ikan Bakar Kinamang during 2017. This research is a descriptive research with qualitative approach. And use case study method. The result of the research shows that the Cost of Fish Raw Material Supplies at Kinamang Fuel Fish Restaurant is still not economical because the purchase (order) is only based on the previous sales estimate, and does not take into account economically the expenses incurred for the purchase and storage of fish raw materials the. Precisely with the calculation of Economic Order Quantity (EOQ), the cost of raw materials inventory of fish is much less, and can determine properly and correctly about the safety stock (safety stock), and reorder (reorder point).
\end{abstract}

Keywords: Inventory Cost, EOQ, Frequency, Safety Stock, ROP

\section{PENDAHULUAN}

Perekonomian di Indonesia saat ini sedang berkembang pesat seiring dengan perkembangan Ilmu Pengetahuan dan Teknologi (IPTEK) yang semakin canggih. Kota Manado menjadi salah satu kota yang maju perekonomiannya karena dampak perkembangan IPTEK. Hal ini terbukti dengan hadirnya sejumlah perusahaan, baik perusahaan kecil, perusahaan menengah dan bahkan perusahaan besar yang beroperasi dengan dukungan kemajuan teknologi. Dewasa ini kota Manado sedang mengalami perkembangan pesat dalam bisnis kuliner. Bisnis kuliner yang berkembang di kota Manado pun sangat beragam. Mulai dari hadirnya bermacam-macam jenis cafe, dan berbagai jenis pilihan makanan di ratusan restoran atau rumah makan.

Kota Manado yang terkenal dengan makanan khasnya bubur Manado atau yang lebih dikenal dengan sebutan tinutuan, ternyata juga menjadi salah satu kota rajanya ikan bakar. Hal ini sudah terbukti dengan hadirnya sejumlah rumah makan ikan bakar yang dapat ditemui di setiap sudut kota Manado. Hal ini tentu menjadi sinyal positif bagi pemerintah dan sejumlah pengusaha rumah makan ikan bakar di kota Manado. Rumah Makan Kinamang adalah salah satu dari ratusan rumah makan ikan bakar yang terkenal dengan ikan bakarnya. Rumah makan ikan bakar Kinamang tersedia berbagai jenis menu pilihan, seperti rahang tuna, dada tuna, baronang, bobara laut, bobara putih, goropa, kakap, tuna bumbu rw, tindarung, daging tuna, oci, mujair, dan cumi. Namun, peneliti lebih memfokuskan penelitian pada rahang tuna, dada tuna, baronang, bobara laut, bobara putih, goropa, dan kakap karena merupakan menu favorit dan paling laris di rumah makan ikan bakar kinamang. 
Proses penjualan ikan bakar di rumah makan ikan bakar Kinamang dilakukan terusmenerus, dan yang menjadi masalah utama dalam perencanaan dan pengendalian persediaan bahan baku utama (ikan), yaitu membengkaknya biaya pemesanan dan biaya penyimpanan bahan baku ikan untuk menjaga kualitas ikan tetap segar, tanpa menggunakan bahan pengawet apapun, sehingga siap untuk diolah dalam proses penjualan di rumah makan Kinamang. Pihak manajer persediaan Kinamang harus bisa mengelola persediaan dengan baik agar dapat memiliki persediaan yang seoptimal mungkin demi kelancaran operasi penjualan di rumah makan dalam jumlah, waktu, dan mutu yang tepat serta dengan biaya yang seminimal mungkin. Berdasarkan penjelasan tersebut, maka penulis tertarik untuk melakukan penelitian dengan judul "Analisis Biaya Persediaan Bahan Baku Ikan dan Perhitungan Economic Order Quantity (EOQ) Pada Rumah Makan Ikan Bakar Kinamang”.

\section{TINJAUAN PUSTAKA}

\subsection{Persediaan}

(PSAK No.14, dikutip dalam Pontoh, 2013:311), dinyatakan bahwa persediaan adalah aset:

1. Tersedia untuk dijual dalam kegiatan usaha biasa.

2. Dalam proses produksi untuk penjualan tersebut.

3. Dalam bentuk bahan atau perlengkapan untuk digunakan dalam proses produksi atau pemberian jasa.

\subsection{Jenis Persediaan}

Menurut Musthafa (2017:49), pada perusahaan industri terdiri dari 3 (tiga) jenis persediaan, yaitu:

1. Persediaan bahan dasar/bahan mentah.

2. Persediaan barang dalam proses.

3. Persediaan barang jadi.

\subsection{Fungsi Persediaan}

Keempat fungsi persediaan (Heizer dan Render, 2010:82) adalah sebagai berikut:

1. Decouple atau memisahkan beberapa tahapan dari proses produksi.

2. Melakukan decouple perusahaan dari fluktuasi permintaan dan menyediakan persediaan barang-barang yang akan memberikan pilihan bagi pelanggan.

3. Mengambil keuntungan dari diskon kuantitas karena pembelian dalam jumlah besar dapat mengurangi biaya pengiriman barang.

4. Melindungi terhadap inflasi dan kenaikan harga.

\subsection{Biaya Persediaan}

Menurut Hansen dan Mowen (2011:208), dalam dunia yang penuh kepastian, dunia di mana permintaan akan suatu produk atau bahan baku diketahui dengan pasti untuk periode waktu tertentu (biasanya satu tahun), terdapat dua biaya utama yang terkait dengan persediaan. Jika persediaan berupa bahan baku atau barang yang dibeli dari sumber luar, maka biaya yang terkait dengan persediaan tersebut disebut biaya pemesanan dan biaya penyimpanan. Jika bahan baku atau barang diproduksi secara internal, maka biaya disebut biaya persiapan dan biaya penyimpanan.

Biaya pemesanan (ordering cost) adalah biaya-biaya untuk menempatkan dan menerima pesanan. Contoh-contohnya mencakup biaya pemrosesan pesanan (biaya administrasi dan dokumen), biaya asuransi untuk pengiriman, dan biaya pembongkaran. Biaya penyimpanan (carrying cost) adalah biaya-biaya untuk menyimpan persediaan. Contohnya adalah asuransi, pajak persediaan, keusangan, biaya peluang dari dana yang terikat dalam persediaan, biaya penanganan, dan ruang penyimpanan persediaan. 


\subsection{Kuantitas Pesanan Ekonomis (Economic Order Quantity-EOQ)}

Menurut Musthafa (2017:51), kuantitas Pesanan Ekonomis (Economic Order QuantityEOQ) merupakan volume atau jumlah pembelian yang paling ekonomis untuk dilaksanakan dalam setiap kali pembelian bahan mentah. Suatu metode untuk menentukan persediaan bahan dasar yang tepat, sehingga tidak mengganggu proses produksi dan biaya yang dikeluarkan tidak terlalu tinggi, digunakan rumus sebagai berikut:

$$
E O Q=\sqrt{\frac{2 \times R \times S}{P \times I}}
$$

Di mana:

EOQ : Kuantitas pemesanan ekonomis

$\mathrm{R} \quad$ : Jumlah (dalam unit) yang diperlukan selama satu periode tertentu

$\mathrm{S} \quad$ : Biaya pesanan setiap kali pesan

$\mathrm{P} \quad$ : Harga pembelian per unit yang dibayar

I : Biaya penyimpanan dan pemeliharaan, dalam persentase dari nilai rata-rata dalam rupiah dari persediaan

Biaya penyimpanan \% terhadap nilai barang (I):

\begin{tabular}{c}
$I=\frac{R \times P}{\text { Total Biaya Penyimpanan }}$ \\
Biaya pemesanan setiap kali pesan $(\mathrm{S})$ : \\
$S=\frac{\text { Total Biaya Pemesanan }}{\text { Frekuensi Pemesanan }}$ \\
\hline
\end{tabular}

\subsubsection{Total Biaya Persediaan (Total Inventory Cost-TIC)}

$$
T I C=\frac{R}{E O Q} S+\frac{E O Q}{2} H
$$

Di mana:

TIC : Total biaya persediaan.

EOQ : Jumlah pemesanan yang ekonomis (unit)

$\mathrm{R} \quad$ : Jumlah (dalam unit) yang diperlukan selama satu periode tertentu

$\mathrm{S} \quad$ : Biaya pemesanan (rupiah/pesanan)

$\mathrm{H}=\mathrm{P} \times \mathrm{I}:$ Biaya penyimpanan (rupiah/unit/tahun)

\subsubsection{Frekuensi Pemesanan Persediaan}

$$
F=\frac{R}{E O Q}
$$

Di mana:

F $\quad$ : Frekuensi pembelian selama satu periode (setahun)

$\mathrm{R} \quad$ : Jumlah (dalam unit) yang diperlukan selama satu periode tertentu

EOQ : Jumlah pemesanan yang ekonomis (unit) 


\subsubsection{Persediaan Pengaman (Safety Stock-SS)}

Menurut Musthafa (2017:54), Safety Stock adalah persediaan pengaman bahan mentah. Apabila pemakaian setiap periode tidak pasti, maka perusahaan perlu mempertahankan persediaan pengaman atau safety stock agar ketidakpastian atau keterlambatan datangnya pesanan yang baru dan pemakaian bahan tidak mengganggu operasi perusahaan.

\begin{tabular}{ll} 
Penggunaan maksimal & A \\
Rata-rata penggunaan & $\mathrm{B}-$ \\
\hline Selisih & $\mathrm{C}$ \\
Waktu tungggu & $\mathrm{D} \times$ \\
\hline Persediaan pengaman & $\mathrm{CD}$
\end{tabular}

\subsubsection{Titik Pemesanan Kembali (Reorder Point-ROP)}

Menurut Musthafa (2017:54), Reorder Point merupakan titik persediaan bahan mentah (sisa masih ada) yang harus dilakukan pemesanan kembali.

$$
\mathrm{ROP}=(\text { Tingkat rata-rata penggunaan } \mathrm{x} \text { Waktu tunggu })+\mathrm{SS}
$$

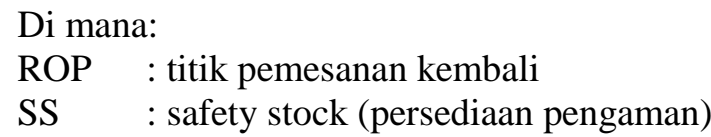

\subsection{Peneliti Terdahulu}

Alfian Fadli tahun 2015 dengan judul Analisis Perencanaan dan Pengendalian Persediaan Bahan Baku Untuk Mengukur Biaya Bahan Baku dan Menunjang Kelancaran Produksi Pakan Ternak Ayam Di PT. X. Hasil penelitian menunjukkan bahwa biaya persediaan bahan baku PT.X unit Sidoarjo untuk memproduksi pakan ternak bisa lebih efisien jika menggunakan metode EOQ.

Olivia Elsa Andira tahun 2016 dengan judul Analisis Persediaan Bahan Baku Tepung Terigu Menggunakan Metode EOQ (Economic Order Quantity) Pada Roti Puncak Makassar. Penerapan metode EOQ pada perusahaan menghasilkan biaya yang lebih murah jika dibandingkan dengan metode yang selama ini diterapkan oleh perusahaan.

\section{METODE PENELITIAN}

\subsection{Jenis Penelitian}

Penelitian ini merupakan penelitian deskriptif dengan pendekatan kualitatif, yaitu dengan mendeskripsikan masalah biaya persediaan bahan baku ikan berdasarkan data yang diperoleh dan diolah, berupa tabel perhitungan biaya persediaan bahan baku ikan dan perhitungan Economic Order Quantity (EOQ) pada RM. Ikan Bakar Kinamang Manado.

\subsection{Tempat dan Waktu Penelitian}

Penelitian ini mengambil tempat di Rumah Makan Ikan Bakar Kinamang Manado. Waktu Penelitian direncanakan dari bulan Februari 2018 sampai dengan selesai.

\subsection{Jenis Data}

Jenis data yang digunakan dalam penelitian ini adalah data kuantitatif dan data kualitatif. Data kuantitatif dalam penelitian ini yaitu perhitungan sejumlah biaya terkait pemesanan dan penyimpanan persediaan bahan baku serta perhitungan Economic Order Quantity (EOQ), safety stock, dan reorder point pada RM. Ikan Bakar Kinamang Manado. Data kualitatif dalam penelitian ini mengenai gambaran umum tentang perusahaan yang berupa sejarah perusahaan, visi dan misi perusahaan, struktur organisasi dan job description serta deskripsi mengenai perbandingan biaya persediaan bahan baku yang meliputi biaya pemesanan dan biaya penyimpanan sebelum dan sesudah menggunakan metode Economic Order Quantity (EOQ) pada RM. Ikan Bakar Kinamang Manado. 


\subsection{Teknik Pengumpulan Data}

Pengumpulan data dilakukan melalui:

1. Peneltian Lapangan (Field Research), melalui observasi, wawancara, dan dokumentasi.

2. Penelitian Kepustakaan (Library Research), yaitu pengumpulan data melalui bukubuku literatur, jurnal dari peneliti terdahulu yang berisi teori atau informasi yang berkaitan dengan penelitian ini.

\subsection{Prosedur Penelitian}

Prosedur penelitian yang akan dilakukan adalah:

1. Penentuan masalah (menemukan masalah)

2. Penetapan latar belakang masalah

3. Perumusan atau identifikasi masalah

4. Penetapan tujuan dan manfaat penelitian

5. Telaah atau studi kepustakaan

6. Penetapan metode penelitian

7. Penyusunan jadwal penelitian

8. Pengumpulan data

9. Pengolahan data

10. Analisis data

11. Penulisan laporan akhir

\section{HASIL PENELITIAN DAN PEMBAHASAN}

\subsection{Hasil Analisis Data}

Biaya pembelian (pemesanan) seluruh jenis ikan pada tahun 2017 adalah sebesar Rp 40.211.200,00 yang terdiri dari biaya telekomunikasi, biaya ekspedisi, biaya bongkar/muat barang, dan biaya administrasi. Biaya ekspedisi untuk setiap jenis ikan berbeda-beda, tergantung dari berapa kilogram pemesanan. Biaya penyimpanan persediaan ikan sebesar Rp 269.888.425,00 selama tahun 2017 secara keseluruhan, yang mana jumlah persediaan yang disimpan saat itu sebanyak $25.401 \mathrm{Kg}$.

\subsubsection{Total Biaya Persediaan Bahan Baku Ikan Selama Tahun 2017}

\subsubsection{Berdasarkan Kebijakan Rumah Makan Ikan Bakar Kinamang}

Diketahui: Dada Tuna

$$
\begin{aligned}
& \text { Jumlah yang digunakan }(\mathrm{R}) \quad=10.065 \mathrm{Kg} \\
& \text { Frekuensi pemesanan } \quad=36 \mathrm{kali} \\
& \text { Biaya sekali pesan }(\mathrm{S}) \quad=\mathrm{Rp} 374.111 \\
& \text { Biaya simpan per } \mathrm{kg}(\mathrm{H}) \quad=\mathrm{Rp} 1.357,5 \\
& \begin{array}{l}
\text { Rata }- \text { rata Persediaan }=\frac{R}{12}=\frac{10.065 \mathrm{Kg}}{12}=838,75 \mathrm{Kg} \\
\hline T I C=(\text { frekuensi pesanan } \times \text { biaya sekali pesan })+(\text { rata }- \text { rata persediaan } \times \text { biaya simpan per } \mathrm{kg}) \\
T I C=(36 \times 374.111)+(838.75 \times 1.357 .5) \\
T I C=R p 14.606 .600,00
\end{array}
\end{aligned}
$$

Jadi, total biaya persediaan dada tuna berdasarkan kebijakan RM. Ikan Bakar Kinamang adalah sebesar Rp 14.606.600,00.

\subsubsection{Berdasarkan Metode EOQ}

$$
\begin{aligned}
& \text { Diketahui: Dada Tuna } \\
& \mathrm{R}=10.065 \mathrm{Kg} \\
& \mathrm{P} \quad=\mathrm{Rp} 60.333,00
\end{aligned}
$$




$$
\begin{array}{|l}
S=\frac{\text { Total Biaya Pemesanan }}{\text { Frekuensi Pemesanan }}=\frac{R p 13.468 .000,00}{36 \mathrm{kali}}=R p 374.111,00 \\
\hline I=\frac{R \times P}{\text { Total Biaya Penyimpanan }}=\frac{10.065 \times R p 60.333,00}{R p 269.888 .425,00}=2,25 \% \\
\hline H=P \times I=R p 60.333,00 \times 2,25 \%=R p 1.357,5
\end{array}
$$

Kebutuhan dada tuna dilihat dari tingkat penjualan pada tahun 2017, diketahui sebesar $10.065 \mathrm{Kg}$. Dan harga pembelian dada tuna pada tahun 2017 rata-rata $\mathrm{Rp} 60.333,00 / \mathrm{Kg}$. Biaya pemesanan setiap kali pesan Rp 374.111,00. Persentase biaya penyimpanan terhadap nilai barang adalah $2,25 \%$, dan biaya penyimpanan dada tuna $\mathrm{Rp} 1.357,5 / \mathrm{Kg}$ setahun.

Sehingga jumlah pembelian (pemesanan) ekonomis dada tuna dapat dihitung, yaitu:

$$
\begin{gathered}
E O Q=\sqrt{\frac{2 R S}{H}} \\
E O Q=\sqrt{\frac{2 \times 10.065 \mathrm{Kg} \times R p 374.111,00}{R p 1.357,5}} \\
E O Q=2.355 \mathrm{Kg}
\end{gathered}
$$

Jadi, jumlah pembelian (pemesanan) ekonomis dada tuna adalah sebesar $2.355 \mathrm{Kg}$ tiap kali pesan.

$$
\begin{aligned}
& T I C=\frac{R}{E O Q} S+\frac{E O Q}{2} H \\
& T I C=\frac{10.065 \mathrm{Kg}}{2.355 \mathrm{Kg}} R p 374.111,00+\frac{2.355 \mathrm{Kg}}{2} R p 1.357,5 \\
& T I C=R p 3.197 .364,00
\end{aligned}
$$

Total biaya persediaan dada tuna berdasarkan metode EOQ adalah Rp 3.197.364,00.

\subsubsection{Frekuensi Pembelian (Pemesanan) Bahan Baku Ikan Selama Tahun 2017}

Diketahui:

$$
\begin{aligned}
\mathrm{R} & =10.065 \mathrm{Kg} \\
\mathrm{EOQ} & =2.355 \mathrm{Kg} \\
F & =\frac{R}{E O Q}=\frac{10.065 \mathrm{Kg}}{2.355 \mathrm{Kg}}=4,3 \mathrm{kali}
\end{aligned}
$$

Jadi, frekuensi pembelian (pemesanan) dada tuna yang paling menguntungkan adalah 4 kali pesan.

\subsubsection{Persediaan Pengaman (Safety Stock-SS) Bahan Baku Ikan Selama Tahun 2017}

Total penjualan keseluruhan dada tuna pada tahun 2017 adalah sebanyak 10.065 $\mathrm{Kg} /$ tahun. Penjualan maksimal terjadi pada bulan Desember yaitu sebanyak $1.105 \mathrm{Kg}$ sebulan 
dan rata-rata penjualan saat itu adalah $44,2 \mathrm{Kg} /$ hari. Waktu tunggu pemesanan dada tuna adalah selama 3 hari. Dan waktu tunggu pemesanan berlaku pada semua jenis ikan.

\begin{tabular}{lll} 
Penjualan maksimal & $44,2 \mathrm{Kg}$ & \\
Rata-rata penjualan & $(33,55 \mathrm{Kg})$ & - \\
\hline Selisih & $10,65 \mathrm{Kg}$ & \\
Waktu tunggu & $3 \mathrm{hari}$ & $\times$ \\
\hline Persediaan pengaman & $31,95 \mathrm{Kg}$
\end{tabular}

Jadi, persediaan pengaman dada tuna adalah sebesar 31,95 Kg.

\subsubsection{Titik Pemesanan Kembali (Reorder Point-ROP) Bahan Baku Ikan Selama Tahun 2017}

Total penjualan keseluruhan dada tuna pada tahun 2017 adalah sebanyak 10.065 $\mathrm{Kg} /$ tahun dan rata-rata penjualan $33,55 \mathrm{Kg} /$ hari.

Tingkat rata-rata penjualan dada tuna $\quad=33,55 \mathrm{Kg} / \mathrm{hari}$

Waktu tunggu $=3$ hari

SS $=31,95 \mathrm{Kg}$

$$
\begin{aligned}
& \mathrm{ROP}=(33,55 \times 3)+31,95 \\
& \mathrm{ROP}=132,6 \mathrm{Kg}
\end{aligned}
$$

\subsection{Pembahasan}

\subsubsection{Total Biaya Persediaan Bahan Baku Ikan Selama Tahun 2017}

Kuantitas pembelian (pemesanan) ikan yang berlebihan dapat berdampak pada meningkatnya biaya persediaan, yang terdiri atas biaya pembelian (pemesanan) dan biaya penyimpanan. Biaya pembelian (pemesanan) persediaan semua jenis ikan berdasarkan total penjualan selama tahun 2017 diketahui sebesar Rp 40.211.200,00. Dan biaya penyimpanan persediaan seluruhnya selama tahun 2017 sebesar Rp 269.888.425,00. Biaya penyimpanan tersebut adalah total keseluruhan biaya penyimpanan dari setiap kilogram ikan yang disimpan. Diketahui persediaan yang disimpan dan terjual selama tahun 2017 berjumlah $25.401 \mathrm{Kg}$.

Berdasarkan analisis data yang dilakukan menggunakan metode EOQ, maka dapat terlihat perbedaan antara total biaya persediaan bahan baku ikan selama tahun 2017 berdasarkan kebijakan RM. Ikan Bakar Kinamang dan Metode EOQ yang dapat dilihat pada tabel 4.10 berikut ini:

Tabel 4.10

Perbandingan TIC Berdasarkan Kebijakan RM. Ikan Bakar Kinamang dan Berdasarkan Perhitungan EOQ

\begin{tabular}{|l|c|c|c|}
\hline \multicolumn{1}{|c|}{ Jenis Ikan } & $\begin{array}{c}\text { TIC Berdasarkan EOQ } \\
\text { (Dalam Rupiah) }\end{array}$ & $\begin{array}{c}\text { TIC RM Kinamang } \\
\text { (Dalam Rupiah) }\end{array}$ & Selisih \\
\hline Dada Tuna & $3,197,364.00$ & $14,606,600.00$ & $11,409,236.00$ \\
\hline Rahang Tuna & $660,557.00$ & $8,101,614.00$ & $7,441,057.00$ \\
\hline Goropa & $882,761.00$ & $6,105,847.00$ & $5,223,086.00$ \\
\hline Bobara Putih & $184,118.00$ & $2,955,303.00$ & $2,771,185.00$ \\
\hline Bobara Laut & $188,314.00$ & $3,524,370.00$ & $3,336,056.00$ \\
\hline Kakap & $303,554.00$ & $3,680,351.00$ & $3,376,797.00$ \\
\hline Baronang & $154,317.00$ & $2,738,702.00$ & $2,584,385.00$ \\
\hline \multicolumn{1}{|c|}{ Total } & $\mathbf{5 , 5 7 0 , 9 8 5 . 0 0}$ & $\mathbf{4 1 , 7 1 2 , 7 8 7 . 0 0}$ & $\mathbf{3 6 , 1 4 1 , 8 0 2 . 0 0}$ \\
\hline
\end{tabular}

\section{Sumber: Data diolah}

Perbandingan total biaya persediaan atau Total Inventory Cost (TIC) berdasarkan kebijakan RM. Ikan Bakar Kinamang sebesar Rp 41.712.787,00 yang artinya jauh lebih besar 
dibandingkan dengan total biaya persediaan atau Total Inventory Cost (TIC) berdasarkan perhitungan EOQ yang hanya sebesar Rp 5.570.985,00. Selisih total biaya persediaan berdasarkan kebijakan RM. Ikan Bakar Kinamang dengan berdasarkan perhitungan EOQ adalah sebesar $\mathrm{Rp} 36.141 .802,00$. Perbedaan total biaya persediaan yang sangat besar ini disebabkan oleh kebijakan RM. Ikan Bakar Kinamang yang melakukan pembelian (pemesanan) ikan berulang kali, yaitu sebulan 3 kali pesan yang artinya 36 kali pesan selama setahun, dengan kuantitas/jumlah pesanan yang sedikit. Sehingga terjadi pemborosan biaya pembelian (pemesanan). Dibandingkan berdasarkan perhitungan EOQ, yang menghasilkan frekuensi pembelian (pemesanan) lebih sedikit, sehingga total biaya persediaan jauh lebih ekonomis.

\subsubsection{Frekuensi Pemesanan Bahan Baku Ikan Selama Tahun 2017}

Frekuensi pembelian (pemesanan) bahan baku ikan berdasarkan kebijakan RM. Ikan Bakar Kinamang selama tahun 2017 rata-rata 3 (tiga) kali pesan setiap bulannya, yang artinya dalam setahun 36 (tiga puluh enam) kali pesan, dan ini berlaku untuk semua jenis ikan yang ada. Sedangkan berdasarkan metode EOQ, frekuensi pembelian (pemesanan) bahan baku ikan jauh lebih ekonomis. Berdasarkan metode EOQ, frekuensi pembelian (pemesanan) dada tuna hanya 4 (empat) kali setahun, rahang tuna dan kakap 2 (dua) kali pesan setahun, goropa 3 (tiga) kali pesan, serta bobara putih, bobara laut, dan baronang yang hanya 1 (satu) kali pesan dalam setahun.

\subsubsection{Persediaan Pengaman (Safety Stock-SS) Selama Tahun 2017}

Pihak RM. Ikan Bakar Kinamang tidak dapat menentukan persediaan pengaman (safety stock) bahan baku ikan selama tahun 2017. Padahal, persediaan pengaman ini sangat penting keberadaannya untuk menghindari kemungkinan terjadi kehabisan stok atau persediaan ikan. Berdasarkan metode EOQ, maka

dapat dihitung dan ditentukan dengan baik persediaan pengaman yang harus disediakan. Persediaan pengaman dada tuna sebanyak $31,95 \mathrm{Kg}$, rahang tuna 43,14 $\mathrm{Kg}$, goropa sebanyak $13,35 \mathrm{Kg}$, bobara putih $8,1 \mathrm{Kg}$, bobara laut $15,3 \mathrm{Kg}$, kakap 8,1 Kg, dan baronang 6,87 $\mathrm{Kg}$.

\subsubsection{Titik Pemesanan Kembali (Reorder Point-ROP) Selama Tahun 2017}

Sama halnya dengan persediaan pengaman (safety stock), titik pemesanan kembali (reorder point) juga tidak dapat ditentukan dengan baik oleh pihak RM. Ikan Bakar Kinamang. Dengan metode EOQ, titik pemesanan kembali (reorder point) dapat ditentukan. Titik pemesanan kembali (reorder point) dada tuna $132,6 \mathrm{Kg}$, rahang tuna 98,4 Kg, goropa 51 $\mathrm{Kg}$, bobara putih $21 \mathrm{Kg}$, bobara laut $33 \mathrm{Kg}$, kakap $27 \mathrm{Kg}$, dan baronang $18 \mathrm{Kg}$.

\section{KESIMPULAN DAN SARAN}

\subsection{Kesimpulan}

Berdasarkan hasil penelitian dan pembahasan, maka dapat disimpulkan sebagai berikut:

1. Total biaya persediaan bahan baku ikan di RM. Ikan Bakar Kinamang berdasarkan kebijakan rumah makan jauh lebih besar dibandingkan dengan total biaya persediaan berdasarkan perhitungan EOQ. Dapat dilihat pada tabel 4.10, dimana biaya persediaan dada tuna Rp 14.606.600,00, sedangkan biaya persediaan dada tuna berdasarkan perhitungan EOQ Rp 3.197.364,00. Biaya persediaan rahang tuna Rp 8.101.614,00, sedangkan biaya persediaan berdasarkan perhitungan EOQ Rp 660.557,00. Biaya persediaan goropa Rp 6.105.847,00, sedangkan berdasarkan perhitungan EOQ Rp 882.761,00. Biaya persediaan bobara putih Rp 2.955.303,00, sedangkan biaya persediaan berdasarkan perhitungan EOQ Rp 184.118,00. Biaya persediaan bobara laut $\mathrm{Rp}$ 3.524.370,00, sedangkan biaya persediaan berdasarkan perhitungan EOQ Rp 188.314,00. Biaya persediaan kakap $\mathrm{Rp} 3.680 .351,00$, sedangkan biaya persediaan berdasarkan perhitungan EOQ Rp 303.554,00. Begitu juga dengan biaya persediaan baronang Rp 
2.738.702,00, sedangkan biaya persediaan berdasarkan perhitungan EOQ Rp 154.317,00. Jadi, total keseluruhan biaya persediaan ikan berdasarkan kebijakan RM. Ikan Bakar Kinamang adalah $\mathrm{Rp} 41.712 .787,00$. Sedangkan total keseluruhan biaya persediaan ikan berdasarkan perhitungan EOQ adalah Rp 5.570.985,00. Dari hasil perhitungan ini terlihat jelas, jika pihak RM. Ikan Bakar Kinamang menggunakan metode EOQ dalam penentuan kuantitas pembelian (pemesanan) persediaan ikan, maka dapat melakukan penghematan biaya sebesar Rp 36.141.802,00.

2. Jika pihak RM. Ikan Bakar Kinamang menggunakan metode EOQ dalam menentukan jumlah pesanan persediaan, maka frekuensi pembelian (pemesanan) yang dilakukan pun jauh lebih ekonomis, dibandingkan hanya berdasarkan kebijakan selama ini yang melakukan pembelian (pemesanan) persediaan ikan sebulan 3 kali pesan untuk setiap jenis ikan. Jadi, selama setahun frekuensi pemesanan sebanyak 36 kali. Hal ini menyebabkan terjadinya pemborosan biaya pembelian (pemesanan). Frekuensi pembelian (pemesanan) berdasarkan perhitungan EOQ untuk dada tuna adalah 4 kali pesan, rahang tuna dan kakap 2 kali pesan, goropa 3 kali pesan, bobara putih, bobara laut dan baronang cukup 1 kali pesan dalam setahun. Terlihat jelas bahwa frekuensi pembelian (pemesanan) berdasarkan perhitungan EOQ lebih sedikit, sehingga mengurangi biaya pembelian (pemesanan) setiap kali pesan. Namun, dengan lebih sedikit frekuensi pembelian (pemesanan), justru kuantitas persediaan sekali pesan bertambah banyak. Dada tuna misalnya, berdasarkan kebijakan RM. Ikan Bakar Kinamang dalam sekali pesan hanya sekitar $300 \mathrm{Kg}$, dengan perhitungan metode EOQ sekali pesan minimal $2.355 \mathrm{Kg}$.

3. Jika pihak RM. Ikan Bakar Kinamang menggunakan metode EOQ, maka dapat dengan mudah menentukan persediaan pengaman untuk berjaga-jaga ketika persediaan menipis. Berdasarkan perhitungan EOQ, safety stock dada tuna sebanyak $31,95 \mathrm{Kg}$, safety stock rahang tuna sebanyak $43,14 \mathrm{Kg}$, safety stock goropa sebanyak $13,35 \mathrm{Kg}$, safety stock bobara putih sebanyak $8,1 \mathrm{Kg}$, safety stock bobara laut sebanyak $15,3 \mathrm{Kg}$, safety stock kakap sebanyak $8,1 \mathrm{Kg}$, serta safety stock baronang $6,87 \mathrm{Kg}$.

4. Pihak RM. Ikan Bakar Kinamang juga dapat menentukan kapan harus melakukan pemesanan ulang metode EOQ. Reorder point (titik pemesanan ulang) dada tuna adalah ketika persediaan tersisa 132,6 Kg, rahang tuna 98,4 Kg, goropa $51 \mathrm{Kg}$, bobara putih 21 $\mathrm{Kg}$, bobara laut $33 \mathrm{Kg}$, kakap $27 \mathrm{Kg}$, dan baronang $18 \mathrm{Kg}$. Apabila pihak RM. Ikan Bakar Kinamang tetap berdasarkan kebijakannya, maka tidak dapat menentukan persediaan pengaman (safety stok) dan batas titik pemesanan ulang yang pas, sehingga secara tidak langsung kehilangan penjualan sekaligus kehilangan pelanggan.

\subsection{Saran}

Saran bagi pihak manajemen RM. Ikan Bakar Kinamang adalah:

1. Sebaiknya pihak manajemen RM. Ikan Bakar Kinamang, khususnya manajer persediaan mempertimbangkan kembali terkait penggunaan metode Economic Order Quantity (EOQ) dalam penentuan jumlah pembelian (pemesanan) persediaan ikan untuk mengurangi biaya pemesanan, sekaligus biaya penyimpanan persediaan, sehingga dapat melakukan penghematan biaya.

2. Penggunaan metode Economic Order Quantity (EOQ) dapat meningkatkan pengendalian terhadap jumlah persediaan terkait safety stock dan reorder point, sehingga proses penjualan di RM. Ikan Bakar Kinamang dapat berjalan dengan efektif dan efisien. 


\section{DAFTAR PUSTAKA}

Andira, Olivia Elsa. 2016. Analisis Persediaan Bahan Baku Tepung Terigu Menggunakan Metode EOQ (Economic Order Quantity) Pada Roti Puncak Makassar. Jurnal Ekonomi Bisnis 21(3): 201-208.

Fadli, Alfian. 2015. Analisis Perencanaan Dan Pengendalian Persediaan Bahan Baku Untuk Mengukur Biaya Bahan Baku dan Menunjang Kelancaran Produksi Pakan Ternak Ayam Di PT. X. Artikel Ilmiah. STIE PERBANAS. Surabaya.

Hansen, Don R dan Mowen, Maryanne M. 2011. Akuntansi Manajerial. Edisi 8. Buku 2. Salemba Empat. Jakarta.

Heizer, Jay dan Render, Barry. 2010. Manajemen Operasi. Edisi 7. Buku 1. Salemba Empat. Jakarta. dan__ 2015. Manajemen Operasi: Manajemen Keberlangsungan dan Rantai Pasokan. Edisi 11. Salemba Empat. Jakarta.

Muthafa. 2017. Manajemen Keuangan. Andi. Yogyakarta.

Pontoh, W. 2013. Akuntansi Konsep dan Aplikasi. Halaman Moeka. Jakarta. 